\title{
Study to Assess the Knowledge on Behavioral Problems of School Children among School Teachers with a View to Develop an Informational Module in Selected Schools at Chhattarpuir, Madya Prdesh
}

\author{
V. Janaki ${ }^{1}$, T. Senthil Thirusangu ${ }^{2}$ \\ 1Principal, ${ }^{2}$ Assistant Professor \\ 1 VAB College of Nursing, Chattarpur, Madhya Pradesh, India \\ ${ }^{2}$ Psychiatric Department, Rama Nursing College, Kanpur, Uttar Pradesh, India
}

\begin{abstract}
How to cite this paper: V. Janaki | T. Senthil Thirusangu "Study to Assess the Knowledge on Behavioral Problems of School Children among School Teachers with a View to Develop an Informational Module in Selected Schools at Chhattarpuir, Madya Prdesh" Published in International Journal of Trend in Scientific Research and Development (ijtsrd), ISSN: 24566470, Volume-3 | Issue-4, June 2019, pp.157-159, URL: https://www.ijtsrd.c om/papers/ijtsrd23 630.pdf

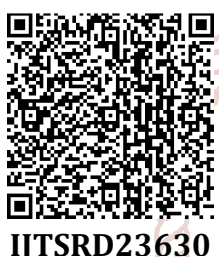

Copyright (C) 2019 by author(s) and International Journal of Trend in Scientific Research and Development Journal. This is an Open Access article distributed under the terms of the Creative Commons

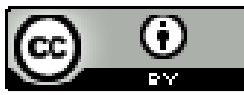

Attribution License (CC BY 4.0) (http://creativecommons.org/licenses/ by $/ 4.0$ )

disorders- disruptive behavior disorder, conduct disorders, emotional disorders, and emotional disturbances.

A teacher is a person who provides students direct classroom teaching, or classroom-type teaching in a nonclassroom setting. Teachers play an influencing role in development of personality. Listening to child's problems is an important skill of a teacher. The early detection and treatment of children with behavioral problems at an early age may reduce treatment costs and improve quality of life of those children. Teachers are the persons who are caring the school going children for a long time with them in schools when comparing to their parents. So school teachers should have adequate knowledge regarding early identification of behavioral problems of school children which will promote the behavioral status of the children. So the researchers are interested to assess the existing knowledge of school teachers regarding behavioral problems of school children. So in this study we are assessing the knowledge on behavioral problems of school children among school teachers by providing an informational module regarding behavioral problems of school children.

\section{Objectives}

1. To assess the knowledge on behavioral problems of school children among school teachers.

2. To associate the level of knowledge on behavioral problems of school children among school teachers with the selected demographic variables

\section{Hypotheses}

H0: There is no significant relationship between the level of knowledge and the selected demographic variables of school teachers.

\section{METHODS AND MATERIALS}

Descriptive research design was adopted for this study. The population for the study includes school teachers who are 
handling the students in the age group between 6-12 years. The sample selected for the present study was 60 school teachers who fulfilled the inclusion criteria. The study settings were Government High School, CHHATTARPUIR, and MADYA PRDESH. Purposive sampling technique was adopted for the study.

\section{Description of the intervention}

Before starting data collection, researcher obtained permission from the Principal in Government Smart Primary School, Chhattarpuir, and Madhya Pradesh. Investigator introduced her to the School teacher and developed professional therapeutic relationship with them. The data was collected through the self structured questionnaire is used to assess the knowledge of behavioral problem of school children, among school teachers.

\section{Data analysis}

The data was analyzed by using descriptive and inferential statistical analysis. The descriptive statistical analysis was done in terms of mean and percentage distribution for the selected demographic variables of school teachers and the inferential statistical analysis was done to associate with the knowledge on behavioral problems of school teachers.

\section{RESULTS}

$>$ The knowledge of school teachers on behavioral problems of school children shows that 15 [25\%] of school teachers having moderately adequate knowledge and $45[75 \%]$ of them have inadequate knowledge and none of the school teachers had adequate knowledge regarding behavioral problems of school children among school teachers. The mean and standard deviation of the study is $14.02+4.26$.

$>$ In association, the level of knowledge among school teachers on behavioral problems with selected demographic variables reveals that none of the demographic variables are non significant with the $P$ value $<0.05$.

$>$ The major findings were the age of the school teachers reveals that $29(48.33 \%)$ of the school teachers belongs to the age group of 36 and above and $6(10 \%)$ of them were 31-35 years of age, Sex of the school teachers shows that $7(11.66 \%)$ of them were males and $53(88.33 \%)$ of them were females, Educational qualification of the school teachers states that $29(48.33 \%)$ of the school teachers have completed their under graduation and 31(51.66\%) of the school teachers have completed their post-graduation, Marital status of the school teachers states that $48(80 \%)$ of them were married and $12(20 \%)$ of them were unmarried, Type of family of the school teachers shows that $31(51.66 \%)$ of them were nuclear family, 28(46.66\%) of them were joint family and $1(1.66 \%)$ was in extended family, Type of residence of the school teachers shows that $40(66.66 \%)$ of them from urban, $20(33.33 \%)$ of them from rural, Teaching experience of the school teachers reveals that $12(20 \%)$ of them have $0-1$ year experience, $4(6.66 \%)$ of them have $2-3$ years of experience, $2(3.33 \%)$ of them have 4 years of experience $3-4$ years of experience and $42(70 \%)$ of them have more than 4 years of experience, The previous knowledge of the school teachers and the table shows that $28(63.33 \%)$ of them have previous knowledge and 32(53.33\%) of them does not have previous knowledge.

\section{DISCUSSION}

This study was conducted to assess the knowledge on behavioral problems of school children among school teachers with a view to develop an informational module in selected schools at puducherry. Descriptive research design was adopted for this study. The population for the study includes school teachers who are handling the students in the age group between 6-12 years. The sample selected for the present study was 60 school teachers who fulfilled the inclusion criteria. The study settings were Government High School, CHHATTARPUIR, and MADYA PRDESH. Purposive sampling technique was adopted for the study. The data was collected through the self structured questionnaire is used to assess the knowledge of behavioral problem of school children, among school teachers.

The first objective of the study is to assess the knowledge on behavioral problems of school children among school teachers. The present study shows that 15 [25\%] of school teachers having moderately adequate knowledge and 45[75\%] of them have inadequate knowledge and none of the school teachers had adequate knowledge regarding behavioral problems of school children among school teachers. The mean and standard deviation of the study is $14.02+4.26$

\section{The second objective of the study is to associate the level of} knowledge on behavioral problems of school children among school teachers with the selected demographic variables. The association of the level of knowledge among school teachers on behavioral problems with selected demographic variables reveals that none of the demographic variables are non significant with the $P$ value $<0.05$.

\section{CONCLUSION}

The conclusion of the present study was shows that not even a single teacher is having an adequate knowledge and majority of them had inadequate knowledge regarding behavioral problems of school children among school teachers. This shows that knowledge of school teachers regarding behavioral problem were poor, so there is a need to improve the knowledge of school teachers about behavioral problem of school children. So health education for school teachers regarding behavioral problems emphasize for the early identification of behavioral problem.

Table 1-Level of knowledge on behavioral problem among school teachers

\begin{tabular}{|c|c|c|c|c|c|}
\hline S. No & Level of knowledge on & Frequency (N=60) & Mean & SD & Percentage \\
\hline 1 & Inadequate knowledge & 45 & 11.96 & 2.46 & $75 \%$ \\
\hline 2 & Moderately adequate knowledge & 15 & 20.20 & 1.66 & $25 \%$ \\
\hline 3 & Moderately adequate knowledge & 0 & 0 & 0 & 0 \\
\hline
\end{tabular}


International Journal of Trend in Scientific Research and Development (IJTSRD) @ www.ijtsrd.com eISSN: 2456-6470

Table 2-Association between the of level of knowledge with the selected demographic variables

\begin{tabular}{|c|c|c|c|c|c|c|c|}
\hline \multirow[b]{2}{*}{$\begin{array}{l}\text { S. } \\
\text { No }\end{array}$} & \multirow{2}{*}{\multicolumn{2}{|c|}{ Demographic variables }} & \multicolumn{2}{|c|}{ Level of knowledge } & \multirow[b]{2}{*}{ Total } & \multicolumn{2}{|c|}{$\times 2$} \\
\hline & & & \multirow{2}{*}{$\begin{array}{c}\text { Inadequate } \\
\text { knowledge } \\
11\end{array}$} & $\begin{array}{c}\text { Moderate } \\
\text { knowledge }\end{array}$ & & $\begin{array}{c}\text { Chi square } \\
\text { Test }\end{array}$ & $\begin{array}{c}\text { P } \\
\text { Value }\end{array}$ \\
\hline \multirow{4}{*}{1} & \multirow{4}{*}{ Age in year } & $20-25$ & & 2 & 13 & \multirow{4}{*}{3.189} & \multirow{4}{*}{3.189} \\
\hline & & $26-30$ & 10 & 2 & 12 & & \\
\hline & & $31-35$ & 3 & 3 & 6 & & \\
\hline & & $36 \&$ above & 21 & 8 & 29 & & \\
\hline \multirow{2}{*}{2} & \multirow{2}{*}{ sex } & Male & 7 & 8 & 29 & \multirow{2}{*}{2.642} & \multirow{2}{*}{0.104} \\
\hline & & female & 38 & 0 & 7 & & \\
\hline \multirow{2}{*}{3} & \multirow{2}{*}{$\begin{array}{l}\text { Educational } \\
\text { Qualification }\end{array}$} & UG & 24 & 5 & 29 & \multirow{2}{*}{1.802} & \multirow{2}{*}{0.179} \\
\hline & & PG & 21 & 10 & 31 & & \\
\hline \multirow{2}{*}{4} & \multirow{2}{*}{ Marital Status } & Married & 34 & 14 & 48 & \multirow{2}{*}{2.222} & \multirow{2}{*}{0.136} \\
\hline & & Unmarried & 11 & 1 & 12 & & \\
\hline \multirow{3}{*}{5} & \multirow{3}{*}{ Type of Family } & Nuclear & 22 & 9 & 31 & \multirow{3}{*}{0.793} & \multirow{3}{*}{0.673} \\
\hline & & Joint & 22 & 6 & 28 & & \\
\hline & & Extended & 1 & 0 & 1 & & \\
\hline \multirow{2}{*}{6} & \multirow{2}{*}{ Residence } & Urban & 29 & 11 & 40 & \multirow{2}{*}{0.4} & \multirow{2}{*}{0.527} \\
\hline & & Rural & 16 & 4 & 20 & & \\
\hline \multirow{4}{*}{7} & \multirow{4}{*}{ Teaching Experience } & 0-1 Year & 10 & 2 & 12 & \multirow{4}{*}{1.397} & \\
\hline & & 2-3 Years & 3 & 1 & 4 & & \\
\hline & & 4-5 Years & 2 & 0 & 2 & & 0.706 \\
\hline & & $\begin{array}{c}\text { More than } 4 \\
\text { Years }\end{array}$ & & 12 & 42 & & \\
\hline & & Yes & 19 & 4 & 28 & & \\
\hline 8 & Previous Knowedge & No & 26 & 6 & 32 & 1.429 & 0.232 \\
\hline
\end{tabular}

\section{REFERENCES}

[1] BimlaKapoor (RNRM)."Textbook of Psychiatric Nursing", volume 11, Mumbai: Kumar publishing house, 2009.

[2] Judith M, Schwtz, Sheila. L. Videveck. Lippincott's, "Manual of Psychiatric Nursing care plan", 7th edition, New Delhi: Lippincott's Williams and Wilkins, 2008.

[3] Wongs. "Essentials of Pediatric Nursing", 7th edition New Delhi: 2005. Elsevier publications, 2005.

[4] Piyush Gupta. "Essentials of Pediatrics Nursing", 2nd edition, New Delhi: CBS Publishers and Distributors, 2007.
[5] NiraiAhuja. "A short book of psychiatry", 18thedition, New Delhi: Medical Publications, 2013.

[6] Lalitha. K. "Textbook of Mental Health and Psychiatric Nursing", 8th edition, Banglore: V. M. G. book house, 2003.

[7] Suraj. Gupta. Shorthand "Textbook of Pediatrics", 10th edition, New Delhi: Jaypee Brothers Publications, 2004.

[8] Basavanthappa. "Textbook of Nursing Research", 1st edition, New Delhi: Jaypee publications, 2000. 